\title{
EXAMINING THE GATEWAY HYPOTHESIS OF DRUG USE IN INDONESIA
}

\author{
Kajian Konsep Gateway Hypothesis Penggunaan Narkoba di Indonesia \\ ${ }^{*}$ Aryo Galih Saloko ${ }^{1,2}$, Asfi Manzilati ${ }^{1}$ \\ ${ }^{1}$ Department of Economic Science, Faculty of Economics and Business, Universitas Brawijaya, Malang, Indonesia \\ ${ }^{2}$ National Narcotics Board, Jakarta, Indonesia \\ ${ }^{*}$ Correspondence: guegalihmen@gmail.com
}

\begin{abstract}
Background: Drug misuse is a global threat, including in Indonesia. Solving issues of drug use is by understanding the drug patterns. One of the important concepts related to public policy in drug addiction is the gateway hypothesis. However, not all researchers support this theory as the initation of drug use is debatable in terms of how a person starts to consume tobacco and alcohol, marijuana, and then other drugs.

Aim: This study identified a initiation sequence of drug use, particularly the gateway from soft to hard drugs and its reverse from hard to soft drug patterns.

Methods: This study employed a dataset of drug user patients aged 14-67 years from the Rehabilitation Center of National Narcotics Board in 2014-2018. The dataset was assessed using the Addiction Severity Index (ASI). Purposive sampling was utilized in the sample selection. The dataset was divided into three subsamples to identify the pattern. The subsamples included regular soft-drug users, regular intermediate-drug users, and regular hard-drug users. This study used a quantitative method and cross-tabulation approach along with descriptive statistics.

Results: Most of the drug users began consuming intermediate drugs and then soft drugs. Only early users followed the gateway pattern, while those in the intermediate and hard drug pattern mostly did not have the gateway pattern.

Conclusion: A policy about prevention of soft drug use (marijuana) in early use may be effective to reduce harder drug use in the future.
\end{abstract}

Keywords: drug use, gateway hypothesis, reversal pattern.

\section{ABSTRAK}

Latar Belakang: Penyalagunaan narkoba telah menjadi ancaman tidak hanya di dunia, namun juga di Indonesia. Mengatasi masalah penggunaan ini salah satunya dengan memahami pola penggunaannya. Salah satu konsep yang penting penting untuk dipahami dalam kebijakan publik terkait ketergantungan narkoba adalah Konsep "gateway hypothesis". Namun, terdapat kontroversi seputar konsep gateway hypothesis tersebut, tidak semua penelitian mendukung konsep inisiasi penggunaan narkoba, mulai dari rokok dan alkohol, berlanjut ke ganja, dan kemudian narkoba jenis lainnya.

Tujuan: Untuk mengidentifikasi urutan dalam inisiasi penggunaan narkoba, khususnya adanya pola gateway (ringan ke berat) dan reversal (berat ke ringan).

Metode: Kami menggunakan data individu pasien pengguna narkoba berusia 14-67 tahun dari Balai Besar Rehabilitasi BNN dari tahun 2014 sampai dengan tahun 2018 dengan menggunakan Indeks tingkat keparahan adiksi/Addiction Severity Index (ASI). Purposive sampling digunakan untuk alat pengambilan sampel. Kami membagi data set menjadi tiga bagian. Yaitu pengguna awal narkoba jenis ringan, pengguna awal narkoba jenis sedang dan pengguna awal narkoba jenis berat. Penelitian ini merupakan penelitian kuantitatif menggunakan analisis tabulasi silang dan juga deskriptif statistik.

Hasil: Sebagian besar sampel pengguna narkoba memulai dengan narkoba dengan jenis sedang dan narkoba jenis ringan. Hanya pengguna awal narkoba jenis ringan yang mengikuti pola gateway, sedangkan untuk pengguna narkoba tingkat sedang dan keras, tidak sesuai dengan pola gateway.

Kesimpulan: Mencegah penggunaan narkoba jenis ringan (ganja) pada awal penggunaan dapat menjadi kebijakan yang efektif mengurangi penggunaan jenis narkoba yang lebih berat di masa mendatang

Kata kunci: gateway hypothesis, penggunaan narkoba, pola reversal. 


\section{INTRODUCTION}

Drug misuse is a global serious issue. The 2019 World Drug Report reports that in 2017, 5.5\% of adolescents and adults worldwide have consumed drugs at least once in the lifetime. The number of individuals with drug use experience had increased by $30 \%$ from 2009 to 2017. It happens partly due to a ten-percent global population growth in the 15-64 age group (UNODC, 2019). In 2017, the Institute for Health Metrics and Evaluation reported that 585,000 people worldwide died because of drug abuse. Most of the deaths are indirectly related to HIV and Hepatitis C, while the rest are directly associated with drug abuse, especially overdoses.

The National Narcotics Board (2017) reports that in Indonesia, the number of people who used drugs was 3.37 million people in 2017. However, the trend was declining from $4.7 \%$ in 2012 to $2.9 \%$ in 2017. The total seizure of marijuana (soft drug) was an increase from 13.9 tons in 2016 to 151.5 tons in 2017 (Kanato, Leyatikul and Choomwattana, 2017, 2018). The 2017 and 2018 ASEAN Drug Monitoring Reports state that the number of other substances, including crystalline methamphetamine (intermediate drug) was 2.63 tons in 2016 and 3.8 tons in 2017, respectively. Furthermore, the reports also mention the number of ecstasy (intermediate drug) rose almost doubled from 1.7 million tablets to 3 million tablets along with other drugs in just one year. In 2017, there were 20 cases with 27 suspects and assets worth more than 7.7 million USD for suppression of money laundering related to narcotics crimes.

To respond to this case, Indonesia has taken appropriate measures. Indonesian president, Joko Widodo, has declared a national emergency on drug users and urged to fight against all types of drug crimes. As Indonesia has a mission to reduce substance abuse and illicit trafficking, the National Narcotics Board is urged to be more effective in coping with the drug problems through demand reduction and supply reduction strategies. Demand reduction strategies are done by strengthening the community perception to fight against drug abuse, while supply reduction strategies are performed through strict and measurable law enforcement to fight against drug syndicates (National Narcotics Board, 2017).

Several factors may affect drug use in Indonesia, such as economic, geographic, and demographic factors. First, economic factors include price disparity, high demand on drugs, income gap, and ASEAN Economic Community Free Trade Agreement (Kanato, Leyatikul and Choomwattana, 2018). In terms of geographical and socio-economic factors, Indonesia has 17,508 islands with a large population of 250 million where domestic and foreign trade unions can operate drug trafficking trafficking (Kanato, Leyatikul and Choomwattana, 2017).

Generally, Indonesian drug users are most likely to use marijuana, then methamphetamine (meth) and ecstasy, respectively (National Narcotics Board, 2017). According to the survey conducted by the National Narcotics Board (2017), almost half of the respondents (47\%) began to use drug with marijuana. Other drugs are benzodiazepine and meth. The NNB reports that most of the drug users used more than one substance. Sixty-eight of 950 New Psychoactive Substances (NPS) have been identified and widely distributed throughout Indonesia by 106 countries and territories circulating the drugs worldwide (UNODC, 2019).

The starting step in overcoming drug use issues is by understanding drug patterns. Many studies have investigated 
the pattern of drug use. Traditionally, it is said that an individual who ever uses a drug tends to have a hierarchical sequential pathway. In other words, early use with alcohol or tobacco among adolescents can make them more addictive, and they will progress to illicit drugs later in adulthood. This concept refers to the "gateway hypothesis" (Kandel, 2002; Vanyukov et al., 2012; Moselhy, 2013; Nkansah-Amankra and Minelli, 2016). Later, the term has extended to include marijuana that leads to the use of other drugs, such as cocaine and heroin (Fergusson, Boden and Horwood, 2006). The gateway hypothesis, defined as a sequence for drug use, usually begins with cigarettes and alcohol and progression to illicit soft drugs, including marijuana, and other hard drugs (Degenhardt et al., 2011; Vanyukov et al., 2012). The validity of the gateway hypothesis is based on two criteria: early use sequence between drug classes and its association in drug use (Kandel, 2002). It means that the sequence is hierarchical as it sees progression from lower drugs to hard drugs with the use of different substances in each sequence.

Many studies support the gateway hypothesis on identifying the progression of drug use. For instance, some studies claim that soft drugs, such as marijuana, have a significant role to progression of using other harder drugs (Kandel, 2002) However, there is a counter-argument against the gateway hypothesis. Several studies claim a "reversal gateway" sequence of substances, implying that drug users initiate illicit-to-licit or hard-tosoft drug sequence (Wells and McGee, 2008; Degenhardt et al., 2011). Some previous studies conducted byWells and McGee (2008) in New Zealand and Degenhardt et al. (2010) in the United States show that the sequence began with the use of hard drugs before marijuana. $A$ cross-national study done by Degenhardt et al. (2011) mentions that drug use rates in some countries were not affected by the prevalence of marijuana, which would be inconsistent with the gateway pattern. Another deviation of the gateway hypothesis in the study of Gfroerer et al. (2002) shows that most of the marijuana users in the United States only used marijuana and never progressed to other dangerous drugs, and this finding appeared to undermine the gateway hypothesis. In a recent report published by the Substance Abuse and Mental Health Services Administration (SAMHSA) in 2018, estimated 118.2 million Americans aged 12 and older had used marijuana at least once (Substance Abuse and Mental Health Services Administration, Rockville, 2019). The Substance Abuse and Mental Health Services Administration (SAMHSA) is the agency within the U.S. Department of Health and Human Services (HHS) that leads public health efforts to advance the behavioral health of the nation. Out of those who have used marijuana, many became marijuana abusers compared to other illicit drugs (Nöel and Wang, 2018). A study by Woodcock et al. (2017) in the United States finds that $20.3 \%$ of current regular heroin users deviated from the gateway hypothesis. Those who initiated heroin use at an earlier age used heroin for a longer duration more frequently than those who followed the gateway hypothesis. Given these contrasting arguments, this present study suggests that it is necessary to understand a sequential order in the initiation of drug use and provide valuable information for policy makers that target to prevent illicit drug prevalence. Policies to prevent the initiation and progression of drug use may be effective for preventing long-term drug prevalence (Deza, 2015). The typical gateway argument calls for policy preventing soft drug use to limit the 
possibility of using other hard drugs (Dewit et al., 2000), while the reversal gateway argument requires policy emphasizing the prevention of soft drug use.

This study aimed to identify a sequential order in the initiation of drug use from both the gateway (soft-to-hard) and reversal gateway (hard-to-soft) patterns. Indonesia, where illicit drug use has prevailed and currently becomes a severe social problem, becomes the study's context. This study utilized a unique dataset of individual drug user patients hospitalized in rehabilitation facilities (inpatient treatment or drug use dependence) from 2014 to 2018, provided by the Narcotic National Board (NNB) Rehabilitation Center, West Java province, Indonesia. Three categories of illicit drugs consist of (i) soft drug (marijuana), (ii) intermediate drug (amphetamine), and (iii) hard drugs, based on the level of harm. Marijuana is a soft drug since its level of harm is relatively moderate and is unlikely to cause addiction (Moselhy, 2013). Amphetamine, a stimulant drug, is considered a relatively hard drug and is more likely to cause addiction (National Institute on Drug Abuse, 2020). The last category is whard drugs, which consist of several types of drugs, including heroin, cocaine, opiate, and benzodiazepine. Hard drugs are classified as the high-ranked group since they are relatively tense with high addiction and are perceived as harmful (Nutt et al., 2007). Among the three categories, the level of harm of marijuana is the smallest. Then, amphetamine has the medium level of harm, and hard drugs, such as heroin and cocaine, has the largest level of harm (Škařupová, 2014)

In addition to the first stage to start illicit drug use, understanding the later stage in the sequence is crucial for policy makers. This study fills the gap which few empirical studies choose the gateway hypothesis in developing countries. Illicit drug use has prevailed in many developing countries that share similar economic, institutional, and social conditions, such as weak institutional frameworks and high poverty rates. An empirical analysis of the Indonesian cases would provide useful guidance for policy maker there. Furthermore, in general, the data of drug use has a reliability issue due to its sensitive question. For example, respondents are reluctant to reveal their real drug use history due to social norm concern, which may result in underreported socially undesirable behavior (Johnson and Fendrich, 2005).

Since most empirical studies on drug use are survey-based, accuracy might be questionable. However, the NNB dataset contains the information of individual drug user patients; tendency to under-report their drug use history would be small. In case of discrepancies in reports from different sources, the information version from patients was considered the most accurate one (Sarkar et al., 2016). Additionally, types of drug use pattern changes over time (UNODC, 2019), and thus a comprehensive examination of drug use with different types of substances is required. Thus, this study considers a broader range of drugs, covering not only marijuana but also other hard drugs, such as amphetamines, opiate, and cocaine.

This study applies to crosstabulation analyses which does not intend to discuss the gateway drug at the first stage since it is impossible to be analyzed due to the unavailable data of non-drug users in the study's database. Instead, this study's analysis evolves around possible determinants of illicit drug use in the sequence seen from the gateway and reversal gateway contexts.

\section{METHOD}


This study used a quantitative method and cross-sectional approach. It analyzed secondary data collected from patients in the Rehabilitation Center of National Narcotics Board in 2014-2018. Samples were selected using a purposive sampling technique. Additionally, crosstabulation analysis and descriptive statistics were carried out.

The Rehabilitation Center of BNN is a government facility located in Bogor District, West Java Province, Indonesia. This data was restricted and the detailed description was obtained by the interview method during the assessment process of prospective patients using the Addiction Severity Index (ASI). ASI is an instrument in interviews collecting individual data about drug use, health, and social problems of people with alcohol and other drug problems (McLellan et al., 1992). There are 3,703 data individuals observation; However, because our focus is only on early drug users who only use one type of drug only 2,811 individual data that qualified for analysis. Individuals who used multiple drugs in the entry stage were excluded (see Table 1.).

To identify a sequential order in the initiation of drug use, this study begins by identifying the samples of drugs. In the dataset, there were seven types of drugs in the regular use and the latest use, namely marijuana, meth, ecstasy, cocaine, opiate, benzodiazepine, and other unclassified drugs. Then, this study simplified the categories from the seven types into three groups based on the most favorable use in Indonesia (National Narcotics Board, 2017), availability of drugs (Degenhardt et al., 2011), level of harms (Nutt et al., 2007). The full sample consisted of three sub-samples: marijuana, amphetamine, and hard drugs (See Table 2). The first sub-sample was marijuana caregorized into marijuana group, the substance with less addiction
(Deza, 2015), thus considered as a soft drug (Moselhy, 2013), and and the most widely used entry level drug in the present. The second sub-sample was an amphetamine, a stimulant drug reacting on the central nervous system (CNS) such as meth and ecstasy; it was considered a hard drug because it as very addictive (National Institute on Drug Abuse, 2020). However, it had a medium level of harm compared to cocaine and opiate/heroine (Nutt et al., 2007). The last sub-sample, the hard drug group, consisted of cocaine, opiate, and benzodiazepine. Those were among seven high-ranked harm, according to parameters of Nutt et al. (2007). Other drugs unclassified are put into other drug groups since most of them contain new psycho substances (NPS) such as synthetic cannabinoids. These unclassified drugs were also considered having more harm than marijuana (Cohen and Weinstein, 2018). Hence, cocaine, opiate, benzodiazepine, and other unclassified drugs had a small number of observations. Therefore, they were included in hard drug groups. Then, this study dropped more than one entry drug from the dataset. In short, it just used the early single drug use categories as the measurement.

Then, the classification was done based on the sequence to identify the initiation order of drug use. The classification procedures were done in stages. First, regular drug use was categorized based on the level of harm, such as soft drug, intermediate drug, and hard drug. Then, the sequence patterns, namely the gateway pattern and the reversal pattern, were classified. To identify the rank, this study proposed some terminologies, namely, soft drug, intermediate drug, and hard drug in the dataset. 
Table 1. Summary of Drug Users based on the Level of Harm from 2014-2018.

\begin{tabular}{|c|c|c|c|c|c|c|c|}
\hline & \multirow{2}{*}{$\frac{2014}{n}$} & \multirow{2}{*}{$\frac{2015}{n}$} & \multirow{2}{*}{$\frac{2016}{n}$} & \multirow{2}{*}{$\frac{2017}{n}$} & \multirow{2}{*}{$\frac{2018}{n}$} & \multicolumn{2}{|c|}{ Total } \\
\hline & & & & & & $\mathrm{n}$ & $\%$ \\
\hline \multicolumn{8}{|l|}{ Entry level drug use } \\
\hline Soft drugs & 236 & 234 & 202 & 188 & 170 & 1,030 & 37 \\
\hline Intermediate drugs & 335 & 372 & 366 & 266 & 314 & 1,653 & 58 \\
\hline Hard drugs & 59 & 34 & 14 & 12 & 9 & 128 & 5 \\
\hline \multicolumn{8}{|l|}{ Lastest level drug use } \\
\hline Soft drugs & 19 & 23 & 18 & 21 & 11 & 92 & 3 \\
\hline Intermediate drugs & 348 & 373 & 390 & 329 & 354 & 1,794 & 64 \\
\hline Hard drugs & 40 & 19 & 10 & 7 & 5 & 81 & 3 \\
\hline Soft drugs and intermediate drugs & 155 & 164 & 127 & 79 & 88 & 613 & 22 \\
\hline Soft drugs and Hard drugs & 17 & 1 & 1 & 2 & 10 & 31 & 1 \\
\hline Intermediate drugs and hard drugs & 28 & 29 & 17 & 19 & 13 & 106 & 4 \\
\hline $\begin{array}{l}\text { Soft drugs, intermediate drugs and } \\
\text { hard drugs }\end{array}$ & 23 & 31 & 19 & 9 & 12 & 94 & 3 \\
\hline
\end{tabular}

Table 2. Characteristics of Drug Users based on Entry Drugs.

\begin{tabular}{|c|c|c|c|c|c|c|}
\hline & \multicolumn{6}{|c|}{ Entry level drugs } \\
\hline & \multirow{2}{*}{\multicolumn{2}{|c|}{ Soft drugs }} & \multicolumn{2}{|c|}{ Intermediate } & \multirow{2}{*}{\multicolumn{2}{|c|}{ Hard drugs }} \\
\hline & & & dru & & & \\
\hline & $\mathrm{n}$ & $\%$ & $\mathrm{n}$ & $\%$ & $\mathrm{n}$ & $\%$ \\
\hline \multicolumn{7}{|l|}{ Gender } \\
\hline Female & 18 & 1.7 & 129 & 7.8 & 11 & 8.6 \\
\hline Male & 1,012 & 98.3 & 1,524 & 0.1 & 117 & 91.4 \\
\hline \multicolumn{7}{|l|}{ Age } \\
\hline Early adolescence $=14-19$ years old & 89 & 8.6 & 145 & 8.8 & 3 & 2.3 \\
\hline Late adolescence $=20-25$ years old & 325 & 31.6 & 471 & 28.5 & 16 & 12.5 \\
\hline Early adulthood $=26-35$ years old & 458 & 44.5 & 735 & 44.5 & 66 & 51.6 \\
\hline Late adulthood $=36-45$ years old & 150 & 14.6 & 256 & 15.5 & 39 & 30.5 \\
\hline Early Elderly $=46-55$ years old & 7 & 0.7 & 40 & 2.4 & 3 & 2.3 \\
\hline Late Elderly $=56-67$ years old & 1 & 0.1 & 6 & 0.5 & 1 & 0.8 \\
\hline \multicolumn{7}{|l|}{ Alcohol } \\
\hline No & 483 & 46.9 & 1,028 & 63.2 & 75 & 58.6 \\
\hline Yes & 547 & 53.1 & 625 & 37.8 & 53 & 41.4 \\
\hline \multicolumn{7}{|l|}{ Religion } \\
\hline Muslim & 871 & 84.6 & 1,309 & 79.2 & 98 & 76.6 \\
\hline Non-Muslim & 159 & 15.4 & 344 & 20.8 & 30 & 23.4 \\
\hline \multicolumn{7}{|l|}{ Education } \\
\hline Low (NS/ES/JHS) & 156 & 15.1 & 280 & 16.9 & 14 & 10.9 \\
\hline Middle (SHS/D) & 753 & 73.1 & 1,139 & 68.9 & 91 & 71.1 \\
\hline High (UG/PG) & 121 & 11.8 & 234 & 14.2 & 23 & 18.0 \\
\hline \multicolumn{7}{|l|}{ Marital status } \\
\hline Divorced & 75 & 7.3 & 157 & 9.5 & 26 & 20.3 \\
\hline Married & 417 & 40.5 & 766 & 46.3 & 40 & 31.3 \\
\hline Single & 538 & 52.2 & 730 & 44.2 & 62 & 48.4 \\
\hline
\end{tabular}




\begin{tabular}{lrrrrrr}
\hline Work status & & & & \\
$\quad$ Unemployed & 395 & 38.3 & 588 & 35.6 & 64 & 50.0 \\
$\quad$ Private firm & 520 & 50.5 & 846 & 51.2 & 57 & 44.5 \\
$\quad$ Public firm & 115 & 11.2 & 219 & 13.2 & 7 & 5.5 \\
\hline Location & & & & & & \\
$\quad$ Rural & 267 & 25.9 & 425 & 25.7 & 6 & 4.7 \\
$\quad$ Urban & 763 & 74.1 & 1228 & 74.3 & 122 & 95.3 \\
\hline$\quad$ Total Observation & 1,030 & 100 & 1,653 & 100 & 128 & 100 \\
\hline $\begin{array}{l}\text { Notes: NS= never go to school; ES =Elementary school; JHS = Junior High School; SHS = Senior High School; D= Diploma; UG= Under Graduate; } \\
\text { and PG= Post Graduate }\end{array}$
\end{tabular}

\section{RESULTS AND DISCUSSION}

\section{Drug Users' Characteristics}

Table 1 shows most of the drug users began consuming intermediate drugs $(n=1,653)$ and soft drugs $(n=1,030)$. While, the lowest share was among the early hard drug users $(n=128)$. According to UNODC (2019), the intermediate drug (methamphetamine) was the most alarming threat in Southeast Asia and East Asia. It has the highest increase in these regions. Meanwhile, the soft drug (marijuana) was the most common gateway drug used by Indonesian drug users (National Narcotics Board, 2017).

Male drug users were dominant in all types of entry level drugs. This result is in line with a report of the Center for Behavioral Health Statistics and Quality (2016) in the United States which mentions that men are more likely to use almost all kinds of illicit drugs than women. Regarding age group, male adults were more likely to use drugs than women (Buccelli et al., 2016). However, female adults tended to have higher progression rates in a regular stage to addiction (Bobzean, DeNobrega and Perrotti, 2014; Poudel and Gautam, 2017).

Next, based on age, most of the drug users started to use drugs in early adulthood (aged 26-35) and late adolescence (aged 19-25). A study conducted by Nkansah-Amankra and Minelli (2016) has found that most drug users in the United States began drug use when they were teenagers. Age of
56 years and more is a state where individuals have less intention to try drugs for the first time. However, regarding the relationship between age and drug use, the elderly in the United States were more likely to begin using drugs with prescribed medications such as opioids and benzodiazepines (Mattson et al., 2017).

Most regular drug users were nonalcoholic, except for regular soft drug users who were alcohol drinkers. Crost and Guerrero (2012) conducted research in Mexico, indicating that the consumption of soft drugs (marijuana) decreased, while the consumption of alcohol increaseds.

In respect with religion, the regular drug users of all drug types were mostly Muslims. There is little evidence regarding the relationship between drug use and certain religion. However, a study conducted by Marsiglia et al. (2005), show that stronger religiosity had more protection against drug use among youth American.

Based on education level, this present study explains all drug users of all types of drugs mostly graduated from senior high school or diploma. High education had the lowest share among the early soft drug users. On the other hand, some intermediate and hard drug users had low education. People finish senior high school or diploma in the adolescence and adulthood period. According to Nkansah-Amankra and Minelli (2016), 
adolescents were dominant drug users in the United States.

The smallest share of marital status in all entry level drugs was among the drug users who got divorced. Most of the early intermediate and hard drug users were married, while single early drug users had more than half share. Some research reveals that drug use was related to marital status. For instance, Kaestner (1997) finds that married people were less likely to use drugs in the United States. These results are also supported by Heinz et al. (2009) who find married people were less likely to use cocaine than unmarried people.

Besides, this study also indicates the early soft drug users and intermediate drug users mostly worked in private companies. Meanwhile, the smallest proportion of work among early hard drug users was public sevants. Working in private firms probably give high pressure on people's mentality compared to working in public service. According to the NNB's report (2017), the majority of drug users among workers use intermediate drugs for increasing stamina to make them less quickly tired. However, few empirical studies discuss about the relationship between drug use and types of employment.

Table 2 also illustrates the majority of all drug users lived in urban areas. Preferences in drug use might vary over various geographic locations. Stoops et al. (2005) have investigated American methamphetamine users and their druguse profiles. Their finding highlights that urban methamphetamine users were more likely to use more than one substance daily due to more drug availability and more lifetime experimentation.

\section{The Sequential Patterns of Drug Use}

The sequential order in the initiation of all drug types is explained from two views: gateway pattern and reversal pattern. Those who regularly consumed soft drugs followed two patterns, gateway patterns, and neither gateway patterns nor reversal patterns. While, the early hard drug users followed the reversal pattern and neither gateway patterns nor reversal pattern. Interestingly, the early intermediate drug users had four patterns, such as gateway pattern, reversal pattern, both gateway and reversal pattern, and neither gateway patterns nor reversal pattern (see Table 3).

The majority of early soft drug users followed the gateway pattern $(91 \%)$, while few progressed to non-gateway pattern and non-reversal pattern. This finding is in line with the gateway hypothesis and its existing studies (Nkansah-Amankra and Minelli, 2016).

More than half of the early hard drug users followed a reversal pattern (53\%), and the rest followed neither gateway patterns nor reversal pattern (47\%). In contrast, among the early hard drug users, the pattern was a reversal pattern, and they remained to use hard drugs at the end. This result is contradict with the gateway hypothesis which the initiation sequence of drug use starts from lowerranked to high-ranked drugs. This result is consistent with previous studies (Degenhardt et al., 2010, 2011), implying that drug users involved a reversal pattern. It is not consistent with the gateway theory because some deviant issues in the hypothesis, which is associated with no other drugs (Woodcock et al., 2017; Nöel and Wang, 2018).

On the other hand, the early intermediate drug users mostly followed both a non-gateway pattern and nonreversal pattern $(85 \%)$, and a small part of them followed gateway pattern, reversal pattern, or both gateway and reversal patterns. The majority of early intermediate drug users apparently deviated 
Table 3. Entry Level Drugs and Sequential Patterns.

\begin{tabular}{lccc}
\hline \multirow{2}{*}{ Patterns } & \multicolumn{3}{c}{ Entry level drugs } \\
\cline { 2 - 4 } & Soft drugs & Intermediate drugs & Hard drugs \\
\hline Gateway only & 943 & 51 & - \\
& $(91 \%)$ & $(3 \%)$ & 68 \\
Reversal gateway only & - & 137 & $(53 \%)$ \\
Both gateway and reversal gateway & - & $(9 \%)$ & - \\
Neither gateway nor reversal gateway & & 31 & 60 \\
& $(96$ & 1,434 & $(47 \%)$ \\
\hline \multirow{2}{*}{ Total } & $(9 \%)$ & $(85 \%)$ & 128 \\
\hline
\end{tabular}

Notes: The share is showed in parentheses.

from the gateway pattern; It may be due to the progression that had no association with other drugs (Woodcock et al., 2017; Nöel and Wang, 2018). Overall, the majority of the early soft drug users followed the gateway pattern, while the early hard drug users followed the reversal pattern. Lastly, the early intermediate drug users had a non-gateway pattern and nonreversal pattern.

However, our study has some limitations. Given our sample is using a clinic-based population of treatment seekers, generalization could be biased. Next, we use simplification by put specific drug use into a group; therefore, there is a possibility the character of the single drug is less accurate. We also consider that we have not been able to quantify or perform the kind of research needed to explore possible causality why these pathways vary of each drug type. Despite these limitations, the present study is the first study of the initiation of drug use and its progression in Indonesia.

\section{CONCLUSION}

In conclusion, this study finds that soft drugs to be more serious and risky subsequent as a gateway drug. The findings indicate that early soft drug use is associated with progression to the harder illicit drug use. This result also can be one of empirical evidence over debatable in legalizing soft drug (marijuana), where the danger of this substance exist in term of the progression. The progress of each three types of the drug differs; however, only regular soft drug users consistent with the gateway hypothesis. Regular intermediate and hard drug user, mostly contradict with gateway hypothesis. These findings suggest that preventing soft drugs (marijuana) in early use may be an effective policy tool to achieve the objective reduces harder drug use in the future.

\section{CONFLICT OF INTEREST}

The author stated that this study did not have any conflicting financial, professional, or personal interests.

\section{REFERENCES}

Bobzean, S. A. M., DeNobrega, A. K. and Perrotti, L. I. (2014) 'Sex differences in the neurobiology of drug addiction', Experimental Neurology, 259, pp. 6474. doi:

10.1016/j.expneurol.2014.01.022.

Buccelli, C. et al. (2016) 'Gender differences in drug abuse in the forensic toxicological approach', Forensic Science International, 265, pp. 89-95. doi: 10.1016/j.forsciint.2016.01.014.

Center for Behavioral Health Statistics and 
Quality (2016) Results From The 2016 National Survey On Drug Use And Health: Detailed Tables Prevalence Estimates, Standard. Available at: https://www.samhsa.gov/data/sites/def ault/files/NSDUH-DetTabs-

2016/NSDUH-DetTabs-2016.pdf.

Cohen, K. and Weinstein, A. M. (2018) 'Synthetic and Non-synthetic Cannabinoid Drugs and Their Adverse Effects-A Review From Public Health Prospective', 6(June), pp. 13-16. doi: 10.3389/fpubh.2018.00162.

Crost, B. and Guerrero, S. (2012) 'The effect of alcohol availability on marijuana use: Evidence from the minimum legal drinking age', Journal of Health Economics, 31(1), pp. 112121.

doi:

10.1016/j.jhealeco.2011.12.005.

Degenhardt et al. (2010) 'Does the "gateway" matter? Associations between the order of drug use initiation and the development of drug dependence in the National Comorbidity Study Replication', NIH Public Access, 39(1), pp. 157-167. doi: $10.1017 / S 0033291708003425$.

Degenhardt et al. (2011) 'Evaluating the drug use "gateway" theory using cross-national data', Drug Alcohol Dependency, 108(2), pp. 84-97. doi: 10.1016/j.drugalcdep.2009.12.001.Ev aluating.

Dewit, D. J. et al. (2000) 'The Influence of Early and Frequent Use of Marijuana on the Risk of Desistance and of Progression to Marijuana-Related Harm', 464, pp. 455-464. doi: 10.1006/pmed.2000.0738.

Deza, M. (2015) 'Is there a stepping stone effect in drug use? Separating state dependence from unobserved heterogeneity within and between illicit drugs', Journal of Econometrics, 184(1), pp. 193-207. doi: 10.1016/j.jeconom.2014.08.005.
Fergusson, D. M., Boden, J. M. and Horwood, L. J. (2006) 'Cannabis use and other illicit drug use: Testing the cannabis gateway hypothesis', Addiction, 101(4), pp. 556-569. doi: 10.1111/j.1360-0443.2005.01322.x.

Gfroerer, J. C., Wu, L.-T. and Penne, M. A. (2002) 'Initiation of Marijuana Use: Trends, Patterns, and Implications', Health (San Francisco). doi: 10.1037/e438082005-001.

Heinz, A. J. et al. (2009) 'Marriage and relationship closeness as predictors of cocaine and heroin use', Addictive Behaviors, 34(3), pp. 258-263. doi: 10.1016/j.addbeh.2008.10.020.

Johnson, T. and Fendrich, M. (2005) 'Modeling Sources of Self-report Bias in a Survey of Drug Use Epidemiology', Annals of epidemiology, 15(5)(13), pp. 381-389. doi:

10.1016/j.annepidem.2004.09.004.

Kaestner, R. (1997) 'The effects of cocaine and marijuana use on marriage and marital stability', Journal of Family Issues, 18, pp. 145-173. doi: $10.1177 / 07399863870092005$.

Kanato, M., Leyatikul, P. and Choomwattana, C. (2017) 'ASEAN drug monitoring report 2016', ASEAN Narcotics Cooperation Center. Available at: https://asean.org/wpcontent/uploads/2016/10/Doc6-ADMReport-2016-as-of-15-November2017-FINAL.pdf.

Kanato, M., Leyatikul, P. and Choomwattana, C. (2018) 'ASEAN drug monitoring report 2017', ASEAN Narcotics Cooperation Center, pp. 1218. Available at: https://asean.org/wpcontent/uploads/2016/10/Doc6-ADMReport-2016-as-of-15-November2017-FINAL.pdf.

Kandel, D. B. (2002) Examining the Gateway Hypothesis: Stages and Pathways of Drug Involvement. In D. 
Kandel (Ed.), Stages and Pathways of Drug Involvement: Examining the Gateway Hypothesis, Cambridge: Cambridge University Press. Edited by C. University. New York: Cambridge: Cambridge University Press. doi: 10.1017/CBO9780511499777.003.

Marsiglia, F. F. et al. (2005) 'God Forbid! Substance Use Among Religious and Nonreligious Youth'. The Educational Publishing Foundation.

Mattson, M. et al. (2017) A day in the life of older adults: Substance use facts, The CBHSQ Report: Center for Behavioral Health Statistics and Quality. Rockville, MD. Available at: https://www.samhsa.gov/data/sites/def ault/files/report_2792/ShortReport2792.pdf.

McLellan, A. T. et al. (1992) 'The fifth edition of the addiction severity index', Journal of Substance Abuse Treatment, 9(3), pp. 199-213. doi: 10.1016/0740-5472(92)90062-S.

Moselhy, H. F. (2013) 'Gateway Hypothesis', Principles of Addiction, pp. 87-95. doi: 10.1016/B978-0-12398336-7.00009-7.

National Institute on Drug Abuse (2020) Drugs, Brains, and Behavior: The Science of Addiction. Available at: https://www.drugabuse.gov/publicatio ns/drugs-brains-behavior-scienceaddiction/preface (Accessed: 1 April 2021).

National Narcotics Board (2017) Executive Summary Survei Nasional Penyalahgunaan Narkoba Di 34 Provinsi Tahun 2017 [Executive Summary National Survey of Drug Abuse in 34 Provinces in 2017]. Jakarta.

Nkansah-Amankra, S. and Minelli, M. (2016) "“Gateway hypothesis" and early drug use: Additional findings from tracking a population-based sample of adolescents to adulthood', Preventive Medicine Reports, 4, pp. 134-141. doi: 10.1016/j.pmedr.2016.05.003.

Nöel, W. and Wang, J. (2018) Is Cannabis a gateway drug?: Key findings and literature review. Washington. Available at: https://www.ncjrs.gov/pdffiles1/nij/252 950.pdf.

Nutt, D. et al. (2007) 'Development of a rational scale to assess the harm of drugs of potential misuse', Lancet, 369(9566), pp. 1047-1053. doi: 10.1016/S0140-6736(07)60464-4.

Poudel, A. and Gautam, S. (2017) 'Age of onset of substance use and psychosocial problems among individuals with substance use disorders', BMC Psychiatry, 17(1), pp. 241-252. doi: 10.1186/s12888-0161191-0.

Sarkar, S. et al. (2016) 'From one substance dependence to another: Are gateway violations common?', Indian Journal of Social Psychiatry, 32(2), p. 171. doi: 10.4103/09719962.181099.

Škařupová, K. (2014) 'The levels of use of opioids, amphetamines and cocaine, and associated levels of harm: summary of scientific evidence', Curr Protoc Microbiol, (March 2014), pp. 121. doi: 10.1002/9780471729259.mc09c02s2 8.Laboratory.

Stoops, W. W. et al. (2005) 'Methamphetamine use in nonurban and urban drug court clients', International Journal of Offender Therapy and Comparative Criminology, 49(3), pp. 260-276. doi: $10.1177 / 0306624 \times 04273438$.

Substance Abuse and Mental Health Services Administration, Rockville, M. (2019) Key substance use and mental health indicators in the United States: 
Results from the 2018 National Survey on Drug Use and Health (HHS Publication No. PEP19 $\square$ 5068, NSDUH Series H$\square 54)$. Rockville, MD: Center for Behavioral Health Statistics and Quality, Subs. doi: 10.3886/icpsr32723.v2.

UNODC (2019) World Drug Report 2019, United Nations. Vienna. Available at: https://wdr.unodc.org/wdr2019/prelaun ch/WDR19_Booklet_1_EXECUTIVE_ SUMMARY.pdf.

Vanyukov, M. M. et al. (2012) 'Common liability to addiction and "gateway hypothesis": Theoretical, empirical and evolutionary perspective', Drug and Alcohol Dependence,
123(SUPPL.1), pp. S3-S17. doi: 10.1016/j.drugalcdep.2011.12.018.

Wells, J. E. and McGee, M. A. (2008) 'Violations of the usual sequence of drug initiation: Prevalence and associations with the development of dependence in the New Zealand Mental Health Survey', Journal of Studies on Alcohol and Drugs, 69(6), pp. 789-795. doi: 10.15288/jsad.2008.69.789.

Woodcock et al. (2017) 'Progression to regular heroin use: Examination of patterns, predictors, and consequences', Physiology \& behavior, 176(5), pp. 139-148. doi: 10.1016/j.physbeh.2017.03.040. 